\title{
KEANEKARAGAMAN SERANGGA DI PERTANAMAN KECOMBRANG (Etlingera elatior JACK) PADA ZONA PENYANGGA KAWASAN TAMAN NASIONAL GUNUNG LEUSER
}

\author{
Diana Rahmi ${ }^{1}$, Ameilia Zuliyanti Siregar ${ }^{1 *}$, dan Suzanna Fitriany Sitepu ${ }^{1}$ \\ ${ }^{1}$ Dept.Agroteknologi, Fakultas Pertanian, Univesritas Sumatera Utara, Indonesia. \\ E-Mail: dianarahmisiregar06@gmail.com, ameilia@usu.ac.id, suzannafitriany@yahoo.co.id
}

\begin{abstract}
ABSTRAK
Keanekaragaman Serangga di Pertanaman Kecombrang (Etlingera elatior Jack) pada Zona Penyangga Kawasan Taman Nasional Gunung Leuser. Kecombrang merupakan tanaman rempah asli Indonesia, dimana sampai kini belum terdeteksi penelitian keanekaragaman serangga dan perananya pada tanaman kecombrang. Tujuan penelitian ini adalah untuk mendapatkan informasi mengenai keanekaragaman serangga, perbandingan pola tanam monokultur dan polikultur dipertanaman kecombrang pada zona penyangga Kawasan Taman Nasional Gunung Leuser. Penelitian ini menggunakan metode survei menggunakan empat perangkap, yaitu perangkap jaring, perangkap jatuh, perangkap kuning, perangkap lampu dengan 4 kali pengamatan di lapangan. Kemudian dilanjutkan dengan identifikasi serangga dilakukan sampai tingkat famili. Hasil identifikasi serangga pada lahan kecombrang monokultur tercatat 917 ekor dengan 7 ordo dan 37 famili, sedangkan pada lahan kecombrang polikultur dikoleksi 1595 ekor dengan 7 ordo dan 42 famili. Perhitungan nilai keanekaragaman pada lahan monokultur dan polikultur tidak berbeda, dimana nilai $H^{\prime}=2,51$ dan 2.52, nilai kekayaan Margallef $(D=5,27$ dan 5,55) dan indeks kemerataan $(E=0,69$ dan 0,67). Analisis nilai kesamaan dua lahan menunjukkan angka 0,67, termasuk ke dalam kategori tinggi pada kesamaan spesies. Ini bermakna ekosistem serangga di zona penyangga kawasan Taman Nasional Gunung Leuser masih alami, diasumsikan belum banyak gangguan pada lingkungan sekitarnya.
\end{abstract}

Kata kunci : Keanekaragaman, Serangga, Kecombrang, Monokultur, Polikultur.

\begin{abstract}
The Diversity of Insects in Torch Ginger Plantations (Etlingera elatior Jack) in the Buffer Zone of Gunung Leuser National Park. Torch ginger is a spice plant native in Indonesia, which.the research on insect diversity and its role in the kecombrang plant has not been detected yet. This study aims to obtain information about insect diversity, comparison between of monoculture and polyculture planting patterns in kecombrang plantations in the buffer zone of the Gunung Leuser National Park area.. This study used a $h$ as: survey method with four treatments used by four insect traps, such as: malaise trap, pitfall trap, yellow trap and light trap. Taxonomy identification was conducted until the family level. The result showed that the amount of insects trapped in monoculture torch ginger planting field were 917 insects with 7 orders and 37 families, while in polyculture planting field recorded were 1595 insects with 7 orders and 42 families. The calculation of diversity index values on monoculture and polyculture Shown did not differenced, where the values of $H^{\prime}=2,51$ and 2,52, the value of Margallef richness $(D=5,27$ and 5,55) and evenness index $(E=$ 0,69 and 0,67). Analysis of the similarity value of the two fields showed the number 0,67, categorized into the high species similarity. This means, the insect ecosystem in the buffer zone of the Gunung Leuser National Park area is still natural, it is assumed that there are not too much disturbance surrounding environment.
\end{abstract}

Key words : Diversity, Insects, Torch Ginger, Monoculture, Polyculture.

\section{PENDAHULUAN}

Taman Nasional Gunung Leuser merupakan salah satu dari 51 taman nasional yang ada di Indonesia. Kawasan hutan TNGL dibagi menjadi beberapa zonasi yaitu zona inti, zona rimba, zona perlindungan, zona pemanfaatan. Areal yang berada diantara zona inti dan zona pemanfaatan atau disebut "buffer zone". Robinson et al., (2013) menyebutkan 
bahwa zona penyangga merupakan areal terbatas yang berfungsi untuk memberikan lapisan perlindungan tambahan dan dan harus bersifat manfaat pada masyarakat lokal untuk dapat mengelola sesuai dengan ketentuan dengan tidak mengganggu daerah inti.Sebagian dari hutan tropis terbesar di dunia terdapat di Indonesia.

Salah satu pemanfaatan lahan yang dilakukan masyarakat di penyangga Taman Nasional Gunung Leuser yaitu dengan budidaya kecombrang. Kecombrang merupakan salah satu jenis tananaman rempah - rempah asli Indonesia yang termasuk dalam famili Zingiberaceae yang penyerbukannya dilakukan oleh serangga dan angin. Tanaman kecombrang merupakan tanaman multiguna karena semua bagian tanaman yaitu rimpang, batang dan bunga dapat digunakan sebagai penyedap rasa, juga pengobatan dan tanaman ini juga berpotensi sebagai sumber insektisida nabati baru (Dadang, 1999, Yang et al., 2004 dan Soenanto, 2005).

Lahan pertanian tanaman kecombrang merupakan habitat bagi keanekaragaman hayati yaitu serangga. Beberapa peran serangga ialah sebagai biondikator, predator, parasitoid, polinator dan scavenger. Serangga polinator sangat mempengaruhi kualitas dan kuantitas tanaman kecombrang. Kramadibrata (1995) menyatakan bahwa keanekaragaman serangga berperan penting dalam menjaga kestabilan pada suatu jenis ekositem. Tingkat keanekaragaman dan kelimpahan serangga yang tinggi menggambarkan bahwa ekosistem tersebut masih alami, sedangkan tingkat keanekaragaman dan kelimpahan serangga yang rendah menunjukkan ekosistem tersebut sudah terganggu (Altieri 1999, Rahmat, 2013).

Melihat pentingnya fungsi serangga dan belum adanya informasi tentang keanekaragaman serangga di pertanaman kecombrang, maka dilakukan penelitian mengenai keanekaragaman serangga di beberapa pertanaman kecombrang (Etlingera elatior Jack) di Zona Penyangga Kawasan Taman Nasional Gunung Leuser di desa Pamah Semelir dan desa Telaga, Kecamatan Sei Bingei. Penelitian ini dilakukan untuk menganalisis keanekaragaman serangga serta peran serangga dalam budidaya pertanaman kecombrang (Etlingera elatior Jack) di Zona Penyangga Kawasan Taman Nasional Gunung Leuser. Hasil penelitian ini diharapkan dapat membantu dalam penyediaan data yang dapat digunakan sebagai referensi bagi berbagai pihak yang membutuhkan.

\section{METODA PENELITIAN}

\subsection{Tempat dan Waktu}

Penelitian ini dilaksanakan di pertanaman kecombrang milik rakyat dengan sistem polikultur di Desa Pamah Semelir dengan ketinggian $1016 \mathrm{~m}$ diatas permukaan laut, dan pertanaman kecombrang dengan sistem monokultur di Desa Telaga, Kecamatan Sei Bingei, Kabupaten Langkat pada ketinggian $998 \mathrm{~m}$ di atas permukaan laut. Pada bulan Juli sampai Agustus 2019.

\subsection{Bahan dan Peralatan}

Perangkap jaring (malaise trap), perangkap jatuh (pitfall trap), perangkap kuning (yellow trap), perangkap lampu (light trap), GPS, lampu LED, wadah plastik, ember, bambu, tripleks, stoples, botol spesimen, rak penyimpanan serangga, mikroskop dengan lensa okuler, loupe, roll meteran, air, detergen, alkohol 70\%, pinset, gunting dan kamera. 


\subsection{Rancangan Percobaan}

Lahan penelitian terdiri dari lahan kecombrang monokultur dan kecombrang polikultur dengan ukuran 0,5 ha. Selanjutnya dibuat sub plot dengan luas $10 \mathrm{~m}$ x $10 \mathrm{~m}$ sebanyak 6 plot yang diletakkan secara diagonal 4 sub plot di sudut dan 2 sub plot di tengah yang diharapkan dapat mewakili keseluruhan populasi.

\subsection{Pengamatan dan Pengumpulan Data}

Perangkap dipasang selama 1 x 24 jam. Pengambilan serangga dilakukan dengan mengambil semua serangga yang tertangkap pada perangkap. Serangga yang didapat kemudian dimasukkan ke dalam botol koleksi yang telah berisi alkohol $70 \%$.

\subsection{Identifikasi Serangga}

Serangga yang tetangkap lalu diidentifikasi di Laboratorium Hama Penyakit Tumbuhan, Fakultas Pertanian, Universitas Sumatera Utara, Identifikasi sampel didasarkan pada buku Panduan Pengenalan Serangga (Borror et al., 1992) dan buku Kunci Determinasi Serangga (Siwi, 1991).

\section{HASIL PENELITIAN DAN PEMBAHASAN}

Jumlah dan Jenis Serangga Tertangkap

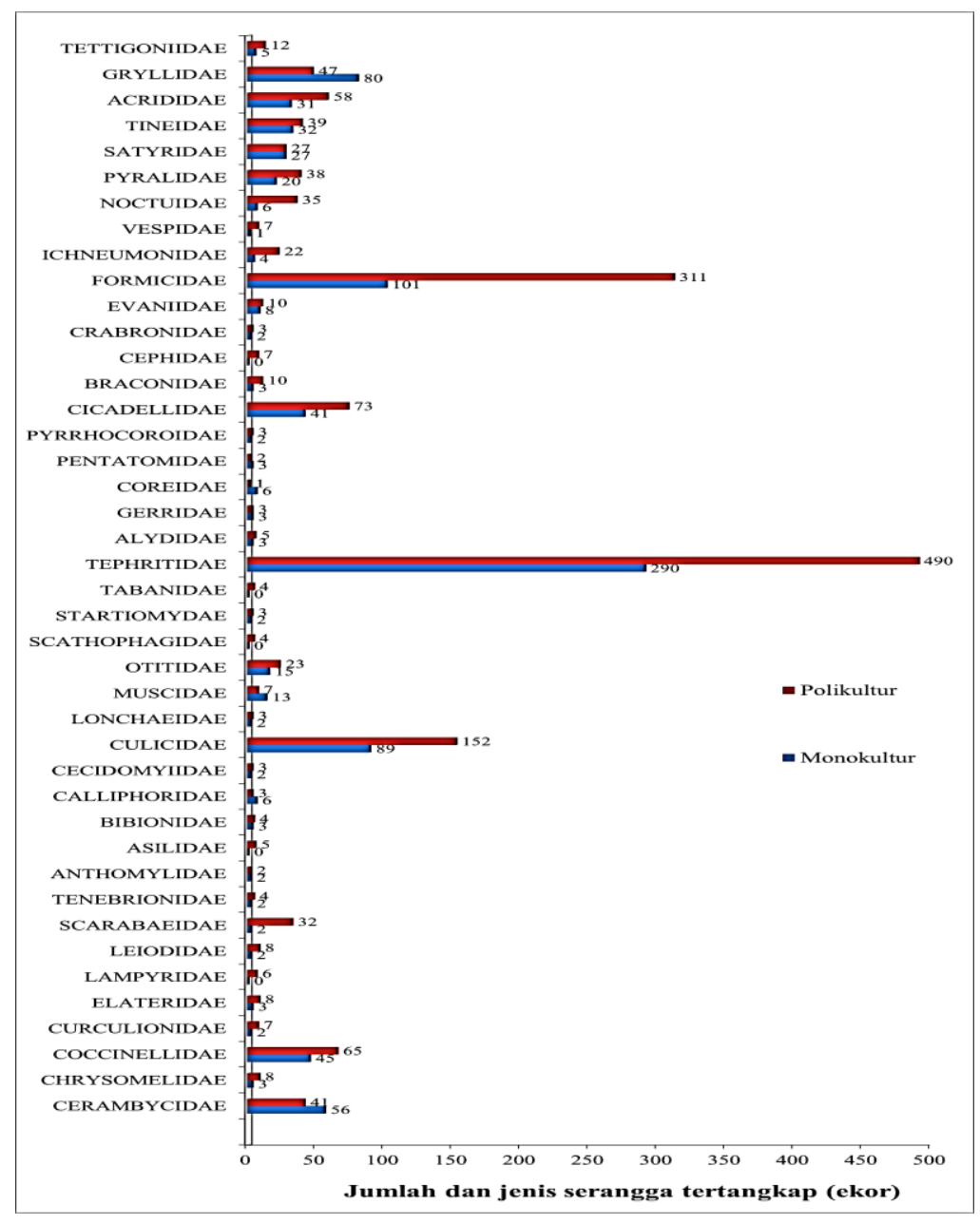

Gambar 1. Histogram Serangga yang Tertangkap pada Lahan Kecombrang Monokultur dan Polikultur. 
Dari hasil penelitian yang dilakukan, diperoleh jumlah dan jenis serangga yang tertangkap pada areal pertanaman kecombrang monokultur dan polikultur terdiri dari 7 ordo dan 37 famili dengan jumlah populasi serangga sebanyak 917 ekor, sedangkan pada lahan kecombrang dengan sistem polikultur yaitu 7 ordo dan 42 famili dan polikultur terdiri dari 7 ordo dan 37 famili dengan jumlah populasi serangga sebanyak 917 ekor, sedangkan pada lahan kecombrang dengan sistem polikultur yaitu 7 ordo dan 42 famili.

Jumlah serangga yang paling banyak tertangkap pada kedua lahan adalah dari famili Tephritidae sebesar 290 ekor di lahan monokultur dan 490 ekor pada lahan polikultur. Hal ini diduga karena famili Tephritidae merupakan bangsa dari Diptera yang mana terdapat banyak tanaman inang di sekitar lahan kecombrang seperti tanaman jeruk, cabai, mangga sehingga ketersediaan makanan menjadi berlimpah. Setelah itu disusul oleh famili Formicidae sebesar 101 ekor di lahan monokultur dan 311 ekor pada lahan polikultur. Hal ini diduga karena famili Formicidae merupakan bangsa dari Hymenoptera yang mana merupakan predator yang terdapat pada pertanaman kecombrang tersebut.

Dari hasil pengamatan jumlah serangga yang paling sedikit tertangkap pada lahan kecombrang adalah famili Vespidae pada lahan monokultur dan famili Coreidae di lahan polikultur. Hal ini diduga karena faktor lingkungan yang tidak sesuai dan tingginya persaingan antar serangga dalam perebutan makanan.

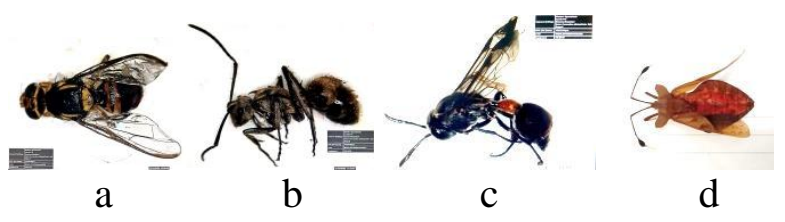

Gambar 2. Foto Serangga Yang Tertangkap Di Lahan Kecombrang

(a) Tephritidae: Diptera (b) Formicidae: Hymenoptera (c) Vespidae: Hymenoptera (d) Coreidae: Hemiptera

Nilai Kerapatan Mutlak, Kerapatan Relatif, Frekuensi Mutlak, Frekuensi Relatif Pada Lahan

Hasil penelitian pada Tabel 1 diketahui bahwa nilai kerapatan mutlak dan kerapatan relatif tertinggi pada lahan kecombrang monokultur terdapat pada Tephritidae dari ordo Diptera dengan nilai $\mathrm{KM}=290$ dan $\mathrm{KR}=31,62$ sedangkan yang terendah terdapat pada Vespidae dari ordo Hymenoptera dengan nilai $\mathrm{KM}=1$ dan $\mathrm{KR}=0,10 \%$. Hal ini sesuai dengan pernyataan Siregar (2015) yang menyatakan bahwa semakin besarnya nilai $\mathrm{KM}$, maka akan semakin besar nilai KR pada varietas situbagendit di Kampung Susuk. Faktor yang mempengaruhi populasi serangga berupa kesesuaian habitat, keutuhan makanan, lingkungan yang mendukung untuk melakukan siklus hidup dan keberadaan musuh alaminya. Nilai frekuensi mutlak dan frekuensi relatif tertinggi pada lahan kecombrang monokultur terdapat pada famili Cerambycidae, Coccinellidae, Culicidae, Muscidae, Otitidae, Tephritidae, Cicadellidae, Formicidae, Pyralidae, Satyridae, Tineidae, Acrididae dan Tettigoniidae dengan nilai $\mathrm{FM}=4$ dan $\mathrm{FR}=3,60 \%$. Nilai frekuensi mutlak dan frekuensi relatif terendah pada lahan pertanaman kecombrang sitem monokultur terdapat pada famili Vespidae dengan nilai $\mathrm{FM}=1$ dan $\mathrm{FR}=0,90 \%$.

Hasil pengamatan kecombrang sistem tanam polikultur diketahui bahwa kerapatan mutlak dan kerapatan relatif 
tertinggi adalah Tephritidae dengan nilai $\mathrm{KM}=490$ dan $\mathrm{KR}=30,72 \%$ sedangkan nilai yang terendah adalah Coreidae dengan nilai $\mathrm{KM}=1$ dan $\mathrm{KR}$ $=0,06 \%$. Pada lahan pertanaman kecombrang sistem pola tanaman polikultur diketahui bahwa nilai frekuensi mutlak dan frekuensi relatif tertinggi terdapat pada famili Cerambycidae, Chrysomelidae, Coccinellidae, Elateridae, Leoiodidae, Scarabaeidae, Asilidae, Culicidae, Muscidae, Otitidae,
Scathophagidae, Tabanidae, Tephritidae, Cicadellidae, Braconidae, Cephidae, Formicidae, Ichneumonidae, Vespidae, Noctuidae, Pyralidae, Satyridae, Tineidae, Acrididae, Gryllidae dan Tettigoniidae dengan nilai $\quad \mathrm{FM}=4$ dan $\mathrm{FR}=2,72 \%$. Hasil perhitungan dapat diketahui bahwa nilai frekuensi mutlak dan frekuensi relatif terendah pada lahan pertanaman kecombrang sitem polikultur terdapat pada famili Coreidae dengan nilai $\mathrm{FM}=1$ dan $\mathrm{FR}=0,68 \%$.

Tabel 1. Nilai Kerapatan Mutlak, Kerapatan Relatif, Frekuensi Mutlak, Frekuensi Relatif pada Lahan Kecombrang Monokultur dan Polikultur

\begin{tabular}{|c|c|c|c|c|c|c|c|c|c|}
\hline \multirow{2}{*}{ ORDO } & \multirow{2}{*}{ FAMILI } & \multicolumn{4}{|c|}{ MONOKULTUR } & \multicolumn{4}{|c|}{ POLIKULTUR } \\
\hline & & KM & KR $(\%)$ & FM & FR $(\%)$ & KM & KR (\%) & FM & FR $(\%)$ \\
\hline \multirow{7}{*}{ COLEOPTERA } & Cerambycidae & 56 & 6,10 & 4 & 3,60 & 41 & 2,57 & 4 & 2,72 \\
\hline & Chrysomelidae & 3 & 0,32 & 3 & 2,70 & 8 & 0,50 & 4 & 2,72 \\
\hline & Coccinellidae & 45 & 4,90 & 4 & 3,60 & 65 & 4,07 & 4 & 2,72 \\
\hline & Curculionidae & 2 & 0,21 & 2 & 1,80 & 7 & 0,43 & 3 & 2,04 \\
\hline & Elateridae & 3 & 0,32 & 3 & 2,70 & 8 & 0,50 & 4 & 2,72 \\
\hline & Lampyridae & 0 & 0 & 0 & 0 & 6 & 0,37 & 3 & 2,04 \\
\hline & Leiodidae & 2 & 0,21 & 2 & 1,80 & 8 & 0,50 & 4 & 2,72 \\
\hline \multirow{16}{*}{ DIPTERA } & Scarabaeidae & 2 & 0,21 & 2 & 1,80 & 32 & 2,00 & 4 & 2,72 \\
\hline & Tenebrionidae & 2 & 0,21 & 2 & 1,80 & 4 & 0,25 & 3 & 2,04 \\
\hline & Anthomylidae & 2 & 0,21 & 2 & 1,80 & 2 & 0,12 & 2 & 1,36 \\
\hline & Asilidae & 0 & 0 & 0 & 0 & 5 & 0,31 & 4 & 2,72 \\
\hline & Bibionidae & 3 & 0,32 & 3 & 2,70 & 4 & 0,25 & 3 & 2,04 \\
\hline & Calliphoridae & 6 & 0,65 & 3 & 0 & 3 & 0,18 & 3 & 2,04 \\
\hline & Cecidomyiidae & 2 & 0,21 & 2 & 1,80 & 3 & 0,18 & 3 & 2,04 \\
\hline & Culicidae & 89 & 9,70 & 4 & 3,60 & 152 & 9,52 & 4 & 2,72 \\
\hline & Lonchaeidae & 2 & 0,21 & 2 & 1,80 & 3 & 1,25 & 2 & 1,36 \\
\hline & Muscidae & 13 & 1,41 & 4 & 3,60 & 7 & 0,43 & 4 & 2,72 \\
\hline & Otitidae & 15 & 1,63 & 4 & 3,60 & 23 & 1,44 & 4 & 2,72 \\
\hline & Scathophagidae & 0 & 0 & 0 & 0 & 4 & 0,25 & 4 & 2,72 \\
\hline & Startiomyidae & 2 & 0,21 & 2 & 1,80 & 3 & 0,18 & 3 & 2,04 \\
\hline & Tabanidae & 0 & 0 & 0 & 0 & 4 & 0,25 & 4 & 2,72 \\
\hline & Tephritidae & 290 & 31,62 & 4 & 3,60 & 490 & 30,72 & 4 & 2,72 \\
\hline & Alydidae & 3 & 0,32 & 3 & 2,70 & 5 & 0,31 & 3 & 2,04 \\
\hline \multirow{4}{*}{ HEMIPTERA } & Gerridae & 3 & 0,32 & 3 & 2,70 & 3 & 0,18 & 3 & 2,04 \\
\hline & Coreidae & 6 & 0,65 & 3 & 2,70 & 1 & 0,06 & 1 & 0,68 \\
\hline & Pentatomidae & 3 & 0,32 & 3 & 2,70 & 2 & 0,12 & 2 & 1,36 \\
\hline & Pyrrhocoroidae & 2 & 0,21 & 2 & 1,80 & 3 & 0,18 & 3 & 2,04 \\
\hline \multirow[t]{2}{*}{ HOMOPTERA } & Cicadellidae & 41 & 4,47 & 4 & 3,60 & 73 & 4,57 & 4 & 2,72 \\
\hline & Braconidae & 3 & 0,32 & 2 & 1,80 & 10 & 0,62 & 4 & 2,72 \\
\hline \multirow{5}{*}{ HYMENOPTERA } & Cephidae & 0 & 0 & 0 & 0 & 7 & 0,43 & 4 & 2,72 \\
\hline & Crabronidae & 2 & 0,21 & 2 & 1,80 & 3 & 0,18 & 3 & 2,04 \\
\hline & Evaniidae & 8 & 0,87 & 3 & 2,70 & 10 & 0,62 & 3 & 2,04 \\
\hline & Formicidae & 101 & 11,01 & 4 & 3,60 & 311 & 19,49 & 4 & 2,72 \\
\hline & Ichneumonidae & 4 & 0,43 & 3 & 2,70 & 22 & 1,37 & 4 & 2,72 \\
\hline
\end{tabular}




\begin{tabular}{|c|c|c|c|c|c|c|c|c|c|}
\hline & Vespidae & 1 & 0,10 & 1 & 0,90 & 7 & 0,43 & 4 & 2,72 \\
\hline \multirow{4}{*}{ LEPIDOPTERA } & Noctuidae & 6 & 0,65 & 3 & 2,70 & 35 & 2,19 & 4 & 2,72 \\
\hline & Pyralidae & 20 & 2,18 & 4 & 3,60 & 38 & 2,38 & 4 & 2,72 \\
\hline & Satyridae & 27 & 2,94 & 4 & 3,60 & 27 & 1,69 & 4 & 2,72 \\
\hline & Tineidae & 32 & 3,48 & 4 & 3,60 & 39 & 2,44 & 4 & 2,72 \\
\hline \multirow{3}{*}{ ORTHOPTERA } & Acrididae & 31 & 3,38 & 4 & 3,60 & 58 & 3,63 & 4 & 2,72 \\
\hline & Gryllidae & 80 & 8,72 & 3 & 2,70 & 47 & 2,94 & 4 & 2,72 \\
\hline & Tettigoniidae & 5 & 0,54 & 4 & 3,60 & 12 & 0,75 & 4 & 2,72 \\
\hline \multicolumn{2}{|c|}{ TOTAL } & 917 & 100 & 111 & 100 & 1595 & 100 & 147 & 100 \\
\hline
\end{tabular}

Nilai Kekayaan Jenis Margalef (Richness Indeks)

Indeks kekayaan jenis berfungsi untuk mengetahui kekayaan jenis setiap

Tabel 2. Nilai Kekayaan Jenis Margalef (Richness Index) spesies dalam setiap komunitasnya yang dijumpai. Nilai indeks kekayaan jenis dapat kita lihat pada Tabel 2.

\begin{tabular}{ccc}
\hline Pengamatan & Pertanaman Monokultur & Pertanaman Polikultur \\
\hline $\mathrm{R}$ & 5,27 & 5,55 \\
\hline
\end{tabular}

Nilai indeks kekayaan jenis serangga (R) pada tanaman kecombrang sistem monokultur yaitu 5,27 dan nilai indeks kekayaan jenis tanaman kecombrang dengan sistem pola tanam polikultur adalah 5,55 yang menunjukkan tingkat kekayaan jenis tergolong tinggi pada kedua lahan kecombrang. Hal ini sesuai dengan kriteria Margalef (1958) yang menyatakan $\mathrm{R}>4$ maka menunjukkan tingkat kekayaan jenis yang tinggi.

\section{Nilai Indeks Kemerataan Serangga (Evennes Index)}

Nilai indeks kemerataan jenis serangga (E') pada tanaman kecombrang sistem monokultur adalah 0,69 yang menunjukkan bahwa kemerataan jenis serangga pada lingkungan lahan ini tergolong tinggi, menurut kriteria jika $\mathrm{E}^{\prime}$ $>0,6$ maka kemerataan jenisnya tergolong tinggi. Hal ini menunjukkan keadaan ekosistem lahan dalam keadaan baik.

Didukung oleh penelitian yang dilakukan Odum (1996) menyatakan bahwa nilai kemerataan (E') berkisar antara $0-1$ yang mana jika nilai kemeratan semakin mendakati 1 maka menggambarkan suatu keadaan dimana semua spesies cukup melimpah.

Pada lahan kecombrang dengan sistem tanam polikultur diketahui nilai indeks kemerataan jenis serangga ( $\left.E^{\prime}\right)$ adalah 0,67 yang menunjukkan bahwa kemerataan jenis serangga pada lingkungan lahan ini tergolong tinggi, menurut kriteria jika $\mathrm{E}^{\prime}>0,6$ maka kemerataan jenisnya tergolong tinggi. 
Tabel 3. Nilai Indeks Kemerataan Serangga (Evennes Index)

\begin{tabular}{ccc}
\hline Pengamatan & Pertanaman Monokultur & Pertanaman Polikultur \\
\hline $\mathrm{E}^{\prime}$ & 0,69 & 0,67 \\
\hline
\end{tabular}

\section{Nilai Indeks Keanekaragaman Jenis Serangga}

Nilai indeks keanekaragaman pada lahan kecombrang sistem monokultur adalah $\quad \mathrm{H}^{\prime}=2,51$ yang termasuk kedalam kondisi lingkungan sedang, Menurut Michael (1995) bila $\mathrm{H}^{\prime}=1-3$ berarti keanekaragaman serangga sedang yaitu mengarah hampir baik dimana keberadaan hama dan musuh alami hampir seimbang. Pada lahan kecombrang sistem pola tanam polikultur nilai indeks keanekaragaman serangga adalah $\mathrm{H}^{\prime}=2,52$. Hal ini menunjukkan bahwa keadaan lingkungan dalam keadaan sedang. Michael (1995) menyatakan bila $\mathrm{H}^{\prime}=1-3$ berarti keanekaragaman serangga sedang yaitu mengarah hampir baik dimana keberadaan hama dan musuh alami hampir seimbang. Pada lahan kecombrang pola tanam monokultur, serangga yang tertangkap adalah 7 ordo 37 famili sedangkan pada lahan kecombrang dengan sistem pola tanam polikultur serangga yang tertangkap yaitu 7 ordo 42 famili. Famili yang tidak tertangkap pada saat penangkapan pada lahan kecombrang sistem monokultur adalah Lampyridae, Asilidae, Scathophagidae, Tabanidae dan Cephidae.

\section{Nilai Kesamaan Serangga pada Dua Lahan (Similirity Index)}

Indeks kesamaan dua lahan $(C s)$ dari Sorensen merupakan indeks untuk melihat seberapa banyak kesamaan jenis individu yang berada pada lahan pertanaman kecombrang monokultur dan kecombrang polikultur dan diperoleh hasil pada Tabel 4 berikut.

Tabel 4. Nilai Kesamaan Serangga pada Dua Lahan (Similirity Index) di Tanaman Kecombrang Monokultur dan Polikultur

\begin{tabular}{cc}
\hline Pengamatan & Indeks Kesamaan Dua Lahan \\
\hline Kecombrang Monokultur dan Kecombrang Polikultur & 0,67 \\
\hline
\end{tabular}

Dari hasil penelitian diperoleh indeks kesamaan dua lahan yaitu jumlah individu serangga pada lahan pertanaman kecombrang monokultur dan lahan kecombrang polikultur adalah 0,67 yang dikategorikan kesamaan spesies tinggi. Semakin besar nilai indeks kesamaan dua lahan, maka kesamaan individu pada dua lahan yang dibandingkan semakin seragam komposisi individunya, Indeks kesamaan dua lahan (Cs) memiliki nilai berkisar antara $0-1$.
Tingginya nilai kesamaan individu pada lahan kecombrang monokultur dan polikultur diduga karena tanaman kecombrang sangat mendominasi pada dua desa ini sehingga sangat memungkinkan perpindahan serangga dari satu wilayah ke wilayah lain. Menurut Penelitian Albab (2016) indeks kesamaan dua lahan (Cs) yang didapati dikategorikan rendah yaitu 0,14 dikarenakan dua tempat yang memiliki karateristik yang berbeda, cagar alam yang merupakan ekosistem alami yang 
mana memiliki komposisi tumbuhan yang tinggi menyebabkan jumlah jumlah jenis spesies masih tinggi, berbeda dengan di lahan pertanian yang merupakan ekosistem buatan yang mana hanya memiliki satu jenis tumbuhan yang mengakibatkan serangga memiliki jenis yang rendah.

\section{Status Peran Seragga yang Tertangkap}

Berdasarkan pengamatan pada lahan pertanaman kecombrang pola tanam monokultur dan polikultur terdapat 14 famili dari 6 ordo serangga yang tergolong ke dalam status dan peran serangga herbivor. Serangga herbivor adalah serangga pemakan tumbuhan, serangga ini dapat memakan berbagai macam bagian tanaman mulai dari akar, batang, bunga daun dan buah. Cara hidup serangga ini sangat beragam, ada yang hidup dipermukaan tanaman, ada juga yang tinggal di dalam jaringan tanaman dengan cara menggorok, selain itu ada yang hidup di dalam tanah di sekitar perakaran. Serangga dianggap sebagai hama ketika keberadaannya merugikan kesejahteraan manusia, estetika suatu produk, atau kehilangan hasil panen. Dengan demikian, walaupun serangga herbivor sangat mendominasi dikedua lahan dipertanaman kecombrang akan tetapi yang tergolong hama belum diketahui.

Berdasarkan hasil penelitian terdapat 2 famili yaitu Noctuide dan Satyridae dari ordo Lepidoptera yang tergolong kedalam serangga polinator. Serangga polinator merupakan serangga yang berperan dalam proses penyerbukan tanaman. Sebagian besar $\pm 80 \%$ tanaman pertanian termasuk kecombrang dalam proses penyerbukannya bergantung atau akan meningkat sejalan dengan meningkatnya kunjungan serangga penyerbuk. Menurut Freitas et al., (1996) tanaman yang mendapat bantuan penyerbuk dalam proses pembuahan akan menghasilkan hasil panen yang lebih banyak

\section{KESIMPULAN}

Kesimpulan dari pelitian ini adalah populasi serangga ditanaman kecombrang monokultur terdapat 917 ekor serangga dengan jumlah tertinggi dari famili Tephritidae dan yang terendah famili Vespidae. Sedangkan pada kecombrang polikultur terdapat 1595 ekor serangga, dengan populasi tertinggi berasal dari famili Tephritidae dan yang terendah dari famili Coreidae dengan nilai indeks keanekaragaman $\left(\mathrm{H}^{\prime}\right)$ pada lahan monokulur 2,51 dan pada lahan polikultur 2,52 yang dinyatakan keanekaragaman sedang. Nilai indeks kemerataan jenis serangga ( $\left.E^{\prime}\right)$ lahan kecombrang monokultur lebih tinggi yaitu 0,69 sedangkan pada kecombrang polikultur adalah 0,67 yang termasuk dalam kategori kemerataan yang tinggi, nilai kekayaan jenis Margalef pada kecombrang monokultur adalah 5,27 dan pertanaman kecombrang polikultur yaitu 5,55 yang menunjukkan tingkat kekayaan jenis yang tinggi dan nilai kesamaan dua lahan yang didapat memiliki kesamaan spesies yang tinggi yaitu 0,67. Analisis nilai kesamaan dua lahan menunjukkan angka 0,67 , termasuk ke dalam kategori tinggi pada kesamaan spesies. Ini bermakna ekosistem serangga di zona penyangga kawasan Taman Nasional Gunung Leuser masih alami, diasumsikan belum banyak gangguan pada lingkungan sekitarnya.

\section{DAFTAR PUSTAKA}

Albab, A. U. (2016). Studi keanekaragaman serangga tanah di cagar alam manggis gadungan dan lahan pertanian desa siman 
kecamatan puncu kabupaten kediri. undergraduate thesis. fakultas sains dan teknologi. Universitas Islam Negri Maulana Malik Ibrahim Malang.

Altieri, M. A. (1999). The ecologycal role of biodiversity in agroecosystems, Agriculture and Ecosystem Enviroment, 74(pp): 19-31.

Dadang. (1999). Insect regulatory and active substances of indonesia plants particulary to the diamond back moth departement of bio regulation Studies, Disertasi. Graduate School of Agriculture. Tokyo University of Agriculture.

Dinas Kesehatan Kabupaten Pakpak Barat. (2016). Manfaat dan khasiat kecombrang bagi kesehatan. Diakses 4 april 2019 dari http://dinkes.pakpakbharatkab.go.id /info-tipskesehatan/manfaat-dankhasiat-kecombrang-bagikesehatan.

Antoro, E. D. (1995). Skrining fitokimia rimpang nicolaia speciosa horan. secara mikrokimiawi kromatografi lapis tipis,dan spektrofotmetri uv. Skripsi. Yogyakarta (ID): Fakultas Farmasi UGM.

Borror, D. J, Tripelhorn C. A, Johnson NF. (1996). Pengenalan pelajaran serangga Ed ke-6., Terjemahan Partosoedjono S. Yogyakarta (ID): Gadjah Mada University Press.

Freitas, B. M, Paxton, R. J. (1996). The role of wind and insects in cashew (Anachardium occidentale) Pollination I NE Brazil. J Agric Sci. 126:319-326.
Habsah M., Ali A.M., Lajis N.H., Sukari M.A., Yap Y. H., Kikuzaki, H. dan Nakatani, N. (2005). Anti tumourpromoting and cytotoxic constituents of Etlingera elatior. Malays J. Med. Vol 12(1). Hal 612.

Kramadibrata, I. (1995). Ekologi hewan. Bandung: ITB Press.

Krebs. (1978). Ecology the experimental analysis of distribusion and abudance. New York: Harper and Row Publication.

Michael, P. (1995). Metode ekologi untuk penyelidikan lapangan dan laboratorium. Terjemahan Yanti R. Koester. UI- Press, Jakarta. Hal 98112.

Odum, E. P. (1996). Dasar-dasar ekologi. Terjemahan Samingan, T. J. Gadjah Mada University Press. Yogyakarta.

Rahmat, A. 2013. Pelatihan Inventarisasi dan Monitoring Flora dan Fauna (Modul Pengenalan Inventarisasi Serangga). Diakses 7 April 2019, dari http://cwmbc.co.id/reportcl/.

Robinson, E. J. Z, Albers H. J and Busby G. M. (2013). The impact of buffer zone size and management on illegal extraction, park protection, ad enforcement. Journals Ecological Economics. 92: 96-103.

Siregar, A. Z. (2015). Perhitungan keanekaragaman serangga. USU. Medan.

Siwi, S. (1991). Kunci determinasi serangga. Yogyakarta: Percetakan Kanisius 
Soenanto, H. (2005). Memusnahkan penyakit dengan obat tradisional. Yogyakarta: Puspa Swara.

Suin, N. M. (1997). Ekologi fauna tanah. Jakarta: Bumi Aksara.
Yang, Y. C., I. K. Park., Kim, E. H, Lee, H. S. and Ahn, Y. J. 2004. Larvicidal activity of medicinal plant ekstracts against aedes aegypti, ochlerotalus togoi and culex pipiens pallens (diptera: culicidae), J. Asia Pasific Entomol, 7(2):227-232. 